Article

\title{
Composition of Garnet from the Xianghualing Skarn Sn Deposit, South China: Its Petrogenetic Significance and Exploration Potential
}

\author{
Fan Yu ${ }^{1}$, Qihai Shu ${ }^{1,2, *(\mathbb{C})}$, Xudong Niu ${ }^{1}$, Kai Xing ${ }^{1,3}$, Linlong Li ${ }^{1,4}{ }^{\text {, David R. Lentz }}{ }^{3}{ }^{(D)}$, \\ Qingwen Zeng ${ }^{1}$ and Wenjie Yang ${ }^{1}$ \\ 1 State Key Laboratory of Geological Processes and Mineral Resources, School of Earth Sciences and \\ Resources, China University of Geosciences, Beijing 100083, China; yufan@cugb.edu.cn (F.Y.); \\ xudong@cugb.edu.cn (X.N.); xingka@cugb.edu.cn (K.X.); lilinlong@pku.edu.cn (L.L.); \\ 2001190044@cugb.edu.cn (Q.Z.); wenjieYang@cugb.edu.cn (W.Y.) \\ 2 Key Laboratory of Deep-Earth Dynamics of Ministry of Natural Resources, Chinese Academy of Geological \\ Sciences, Beijing 100037, China \\ 3 Department of Earth Sciences, University of New Brunswick, Fredericton, NB E3B 5A3, Canada; \\ dlentz@unb.ca \\ 4 School of Earth and Space Sciences, Peking University, Beijing 100871, China \\ * Correspondence: qshu@cugb.edu.cn; Tel.: +86-10-82322750
}

Received: 11 April 2020; Accepted: 15 May 2020; Published: 18 May 2020

\begin{abstract}
The Xianghualing skarn Sn deposit in the southwestern part of the southern Hunan Metallogenic Belt is a large Sn deposit in the Nanling area. In this paper, the garnet has been analyzed by laser ablation-inductively coupled plasma-mass spectrometry (LA-ICP-MS) to obtain the concentrations of the major and trace elements. The results reveal that the garnets from the Xianghualing deposit mainly belong to andradite-grossular (grandite) solid solution and are typically richer in $\mathrm{Al}$ than in Fe. They show enrichment in heavy rare earth elements (HREEs) and notably lower light rare earth elements (LREEs), and commonly negative Eu anomalies, indicative of a relatively reduced formation environment. The garnets have high Sn concentrations between 2313 ppm and $5766 \mathrm{ppm}$. It is also evident that there is a positive correlation between $\mathrm{Sn}$ and $\mathrm{Fe}$, suggesting that $\mathrm{Sn}^{4+}$ substitutes into the garnets through substituting for $\mathrm{Fe}^{3+}$ in the octahedral position. Combined with previous studies, it can be recognized that the Sn concentrations of garnet in skarn Sn deposits are generally high, whereas the $\mathrm{W}$ concentrations are relatively low. This is just the opposite in garnets from skarn $\mathrm{W}$ deposits that typically have high $\mathrm{W}$, but low $\mathrm{Sn}$ concentrations. In polymetallic skarn deposits with both economic $\mathrm{Sn}$ and W, the concentrations of both metals in garnets are relatively high, although varying greatly. Therefore, the $S n$ and $W$ concentrations in garnets can be used to evaluate a skarn deposit's potential to produce Sn and (or) W mineralization, which is helpful in exploration.
\end{abstract}

Keywords: garnet; LA-ICP-MS; tin; skarn deposit; Xianghualing

\section{Introduction}

The Xianghualing skarn Sn deposit is an important skarn deposit in the center of the Nanling Range, which is situated in the northern part of Linwu County, southern Hunan Province. It contains $0.17 \mathrm{Mt}$ Sn with a grade ranging from $0.93 \%$ to $1.39 \%$, and ranks the 10 th largest among the Sn skarns in China [1]. The deposit has been widely investigated since the 1980s, which provides systematic understanding of the regional metallogenic background [2], geological characteristics, ore genesis [3-5], geochronology, geochemistry of rocks and ores in the mining district [6,7], and crystal chemistry of Sn-bearing minerals [8]. Previously, many attempts have been made to reveal the $\mathrm{Sn}$ mineralization 
potential by geochemical studies on Sn-bearing magmatic minerals (e.g., titanite) in the Xianghualing granite [9-11], but to date relatively little attention has been paid to skarn minerals. Garnet is one of the most common minerals in skarn deposits [12-15] and is also a Sn-rich mineral [16,17]. The compositional variations of garnet can reflect its specific ore-forming environment and processes [18-22]. In addition, the contents of some metal elements (e.g., $\mathrm{Sn}, \mathrm{W}$, and Mo) in garnet can also indicate their abundances in the original hydrothermal fluids, which, in turn, can be used in evaluating the potential of economic mineralization of these metals [23-27].

This paper reports the major and trace elements of the garnets from the Xianghualing skarn Sn deposit, which provide insights into the formation conditions of garnets and also the substitution mechanisms of Sn into garnets. Besides, on the basis of a comparison of the garnet compositions from Xianghualing with several other previously studied Sn $(-W)$ deposits, we suggest that the Sn and W concentrations in garnets could be important indicators for $\mathrm{Sn}$ and/or W mineralization and therefore can be potentially used in guiding exploration.

\section{Geological Setting}

\subsection{Regional Geology}

The studied area in the middle of the Nanling tectono-magmatic belt has a history of multicycle tectonic evolution including several magmatic episodes (Figure 1), and it also contains abundant mineral resources [28]. The region is characterized by exposed shallow-marine clastic sedimentary rocks from Devonian to Triassic, with a small amount of carbonate rocks. Folds and faults are widely developed in this area, resulting in the uplift of basement and the metamorphism of Neoproterozoic to Cambrian (Sinian) sedimentary rocks, the strong folding of Devonian-Permian carbonate rocks, and the general deformation of Upper Permian-Triassic sequences. The pre-Jurassic tectonic-magmatic activities were overprinted by Jurassic-Cretaceous tectonic events, resulting in the formation of NNE-directed rift-related basins and deep faults [29]. NW- and NE-trending faults form the principal geological framework of the region, among which the Chenzhou-Shaoyang Fault and the Chaling-Linwu Fault are the major structures controlling the distribution of granitic intrusions and mineral deposits [30]. The magmatic rocks in the study area were mainly formed in three stages: Silurian, Triassic, and Jurassic, and among them the Jurassic magmatism is the most extensive [31-34]. 


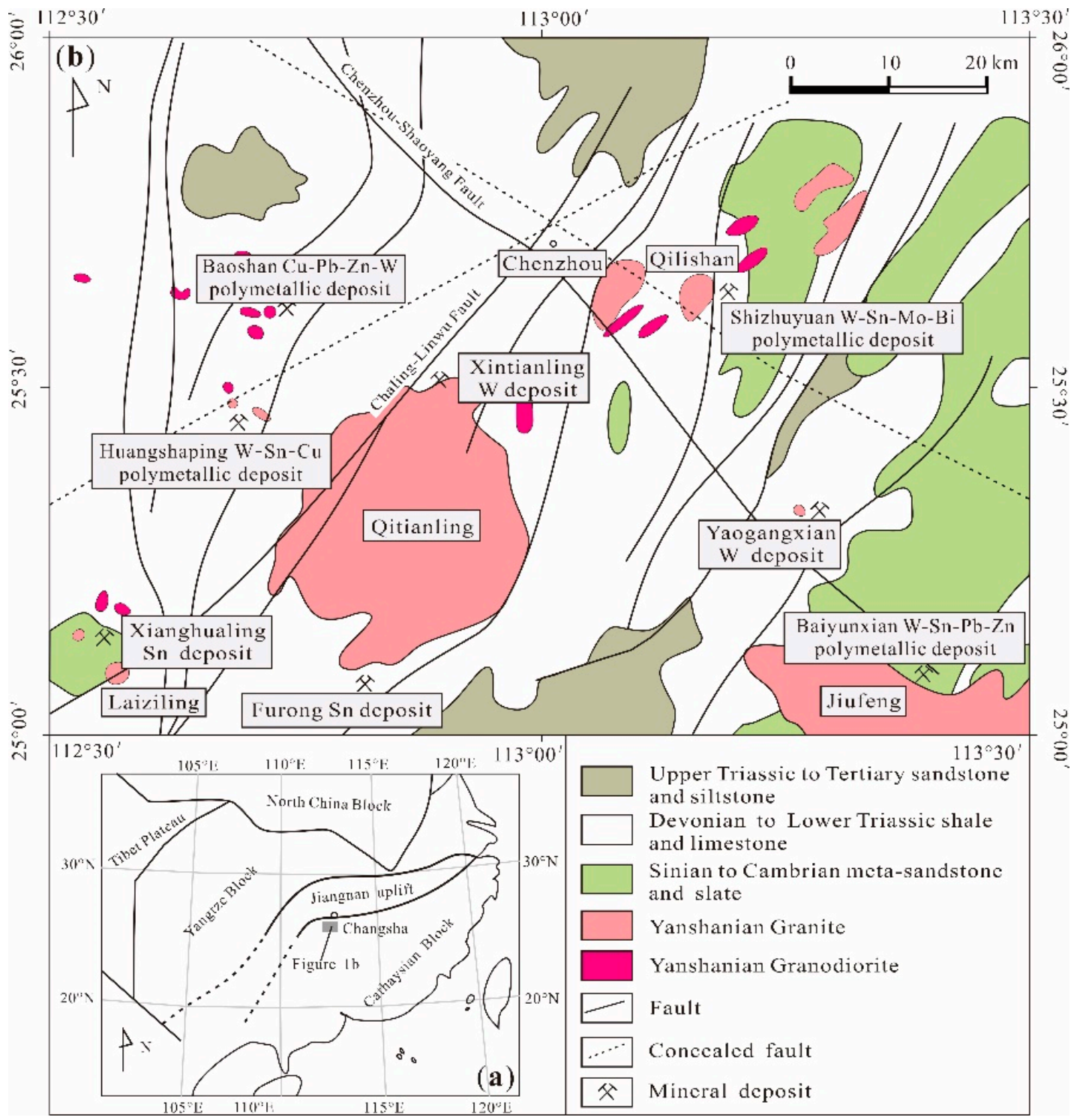

Figure 1. Regional geology of the central Nanling region and the location of the Xianghualing skarn Sn deposit, southeastern China (modified after [6,30]). (a): Tectonic map of South China, showing the location of southern Hunan Province; (b): Geological map of southern Hunan Province, showing the distribution of intrusive rocks and major W-Sn deposits.

\subsection{Geology of the Deposit}

The Xianghualing deposit is located in the northern part of the southern Hunan Province, which is near the center of the Nanling Range [29]. It is one of the largest $S n(-W)$ deposits in the southwestern part of the South Hunan Metallogenic Belt, and tectonically it lies in the intersection area between the NE-trending, deep-seated Chenzhou-Linwu fault zone and the S-trending fault zone. The study area appears as a NE-trending tectono-magmatic dome, which is due to Jurassic magmatic diapirism under a regional extensional setting [6]. The Cambrian slate and meta-sandstone are the main components of the core of the Xianghualing deposit (Figure 2), and the flanks are mainly composed of the Devonian clastic rocks, including the Middle Devonian Tiaomajian Formation conglomerates, sandstones, and shales, the Middle Devonian Qiziqiao Formation limestone and dolomites, and the Upper Devonian Shetianqiao Formation dolomitic limestones and sandstones. In addition, Carboniferous carbonates and Jurassic clastic rocks are also present locally [35]. The Cambrian and Middle Devonian strata are considered to be the major host rocks in the Xianghualing Sn deposit $[29,36]$. The Laiziling and Jianfengling stocks are the two largest granitic stocks in this area, which intrude into Cambrian 
meta-sandstone and Devonian carbonate of the Tongtianmiao dome, respectively. The Laiziling intrusion can be divided into four vertical zones from the base to the top: albite-microcline granite zone, albite granite zone, greisen zone, and pegmatite zone [30,32]. The $\mathrm{U}-\mathrm{Pb}$ zircon age determined from the Laiziling Granite is $155 \pm 2 \mathrm{Ma}$ [37].

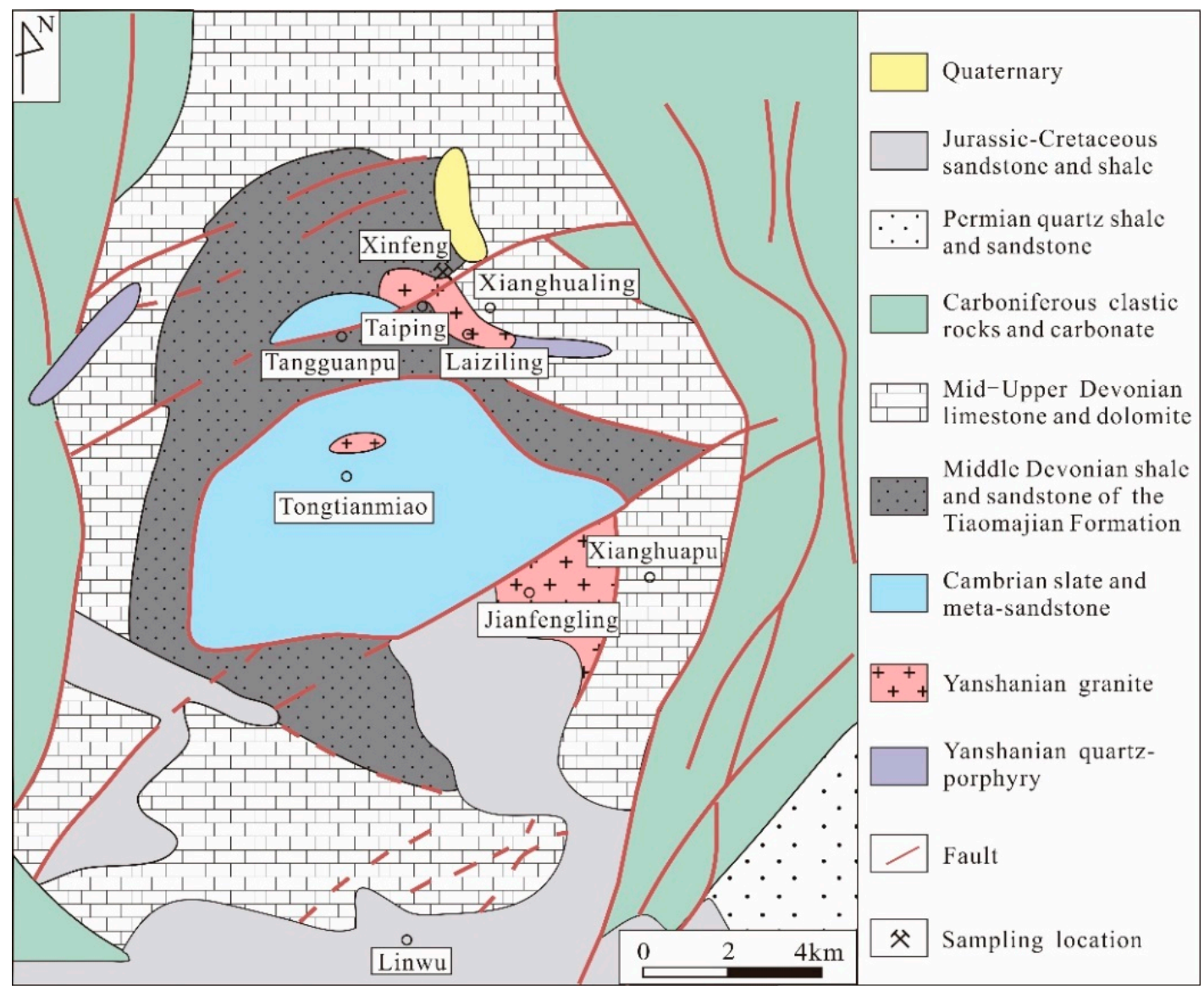

Figure 2. Geological map of the Xianghualing skarn Sn deposit (modified after [6]).

The Xianghualing deposit is a stratabound skarn Sn deposit [5], and the orebodies are mainly stratiform, pipe- and vein-like in shape [38-40]. Field investigations have revealed three major stages of skarn alteration and metal mineralization in the Xianghualing deposit: (1) A prograde pre-mineralization skarn stage (Figure 3a), followed by (2) a dominant Sn-mineralization stage with significant retrograde alteration, and finally (3) a subordinate $\mathrm{Pb}-\mathrm{Zn}$ sulfide stage. Typical minerals of the prograde stage consist of garnet, pyroxene and olivine. The Sn mineralization stage is mainly composed of cassiterite, with retrograde minerals including actinolite, tremolite, chlorite, vesuvianite and quartz. Retrograde alteration often overprinted prograde garnet-bearing assemblages. The $\mathrm{Pb}-\mathrm{Zn}$ sulfide stage is composed of $\mathrm{Pb}-\mathrm{Zn}$ sulfides, with minor pyrite, pyrrhotite and arsenopyrite (Figure 3b), as well as coexistent phlogopite, chlorite, fluorite, quartz and calcite (Figure 3). The ore mineralization is generally zoned in the altered country rocks surrounding the plutons: Sn mineralization occurs in skarns proximal to the granites and $\mathrm{Pb}-\mathrm{Zn}$ sulfides in more distal areas away from the granites [30]. The cassiterite $\mathrm{U}-\mathrm{Pb}$ dating and muscovite ${ }^{40} \mathrm{Ar}-{ }^{39} \mathrm{Ar}$ dating for the Xianghualing deposit gave two ages of $157 \pm 6 \mathrm{Ma}$ and $154.0 \pm 1.1 \mathrm{Ma}[35,38]$, respectively; these results are consistent with the zircon $\mathrm{U}-\mathrm{Pb}$ dating results of the Laiziling intrusion, implying that the magmatism and mineralization could be genetically related and then quickly cooled below the muscovite Ar retention blocking temperature $\left(<350{ }^{\circ} \mathrm{C}\right)$. 


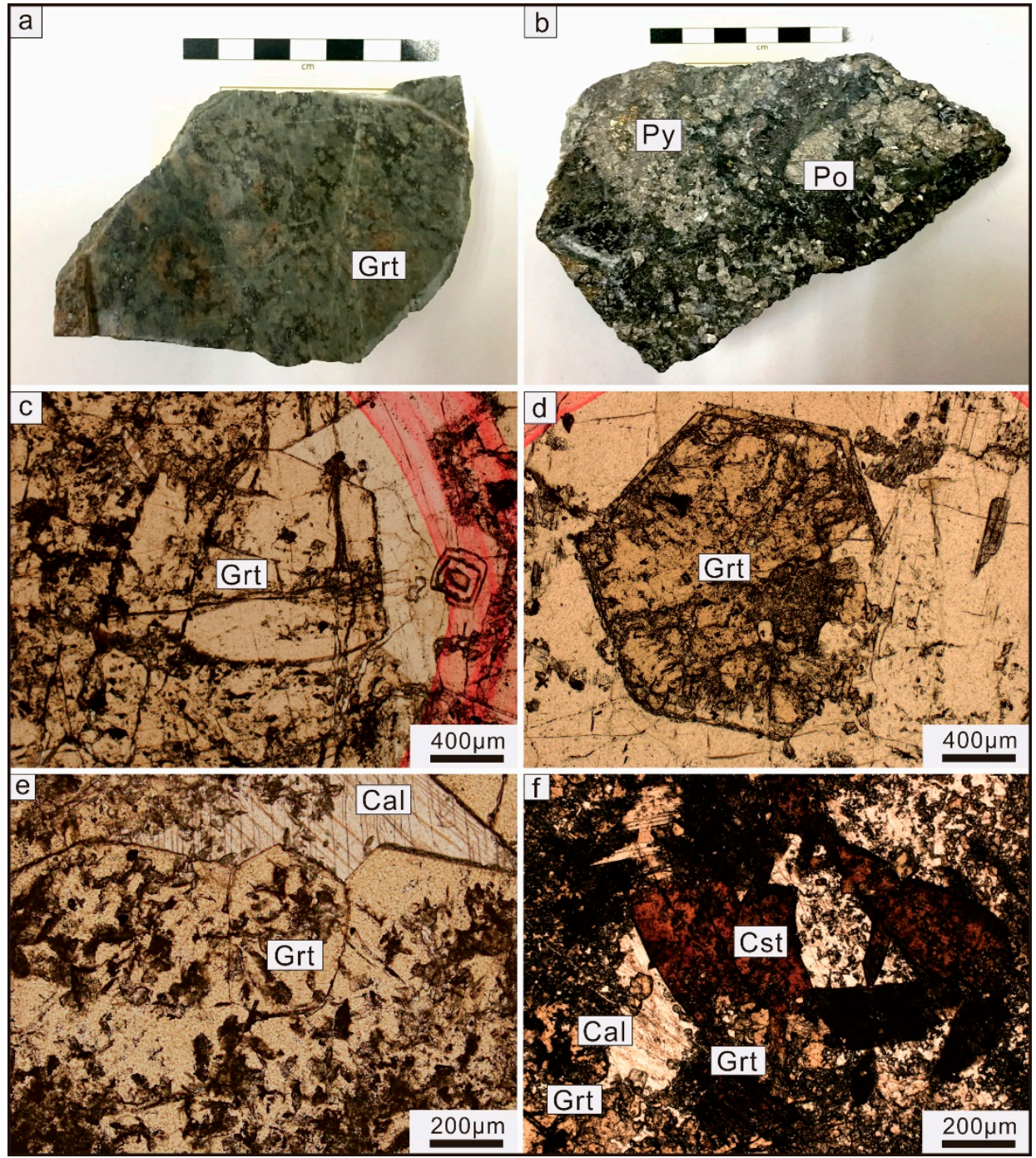

Figure 3. Photos of hand specimens and thin sections of samples from the Xianghualing skarn Sn deposit. (a) Massive garnet-bearing skarn in reddish brown; (b) massive sulfide ore containing pyrite and pyrrhotite; (c) an euhedral garnet crystal; (d) an euhedral garnet hydrothermally altered by later retrograde minerals; (e) the gaps between garnet grains filled with later calcite; (f) garnet grains postdated by later calcite and cassiterite. Abbreviations: Cal = calcite; Cst = cassiterite; Grt = garnet; Po $=$ Pyrrhotite and Py $=$ Pyrite .

\section{Sampling and Analytical Methods}

The samples analyzed in this study were all collected from the Xianghualing mining area (Figure 2). Generally, the garnet could be divided into two types. The first type garnet is euhedral and larger in size ( $>3 \mathrm{~mm}$ ) (Figure 3c-e); the second type is anhedral and much smaller $(<100 \mu \mathrm{m})$ (Figure 3f), and is clearly overprinted by later retrograde alteration. Based on microscopic observation, neither garnet type has obvious growth zoning. In this study, three garnet samples (XHL-1 and XHL-2 of the first type, and XHL-3 of the second type) have been selected for laser ablation-inductively coupled plasma-mass spectrometry (LA-ICP-MS) element analysis.

The analysis was performed at the Ore Deposit and Exploration Centre (ODEC), Hefei University of Technology, Hefei, China, using an Agilent 7900 ICP-MS coupled with a $193 \mathrm{~nm}$ ArF excimer Resonetics RESOlution laser-ablation system, named PhotonMachines Analyte HE. Helium $(0.90 \mathrm{~L} / \mathrm{min})$ and argon $(0.87 \mathrm{~L} / \mathrm{min})$ were used as the carrier gas and make-up gas, respectively. The two gases were mixed through a T-joint before entering ICP. The laser was operated at $8 \mathrm{~Hz}$, with a laser fluency of $2 \mathrm{~J} / \mathrm{cm}^{2}$, and a spot size of $30 \mu \mathrm{m}$. Each analysis included $20 \mathrm{~s}$ of background acquisition (gas 
blank), $40 \mathrm{~s}$ of data acquisition, and again $20 \mathrm{~s}$ of background signal, and therefore the total time for every spot analysis was $80 \mathrm{~s}$ [41]. The external standards were BCR-2G, NIST610, and NIST612, analyzed once every 10 analyses in order to correct the time-dependent drift of sensitivity and mass discrimination. The laser for LA-ICP-MS mapping was operated at $10 \mathrm{~Hz}$, with a sample movement speed of $40 \mu \mathrm{m} / \mathrm{s}$. The mapping was conducted in line scanning style, with each line being parallel and the size consistent with the laser ablation spot [41]. Standards were analyzed in duplicate at the start and end of each mapping run, which included reference glasses NIST610, NIST612 and garnet standard MON-GT. The total analysis time of mapping was approximately $2 \mathrm{~h}$ for each sample [42]. Elements analyzed in this study include $\mathrm{Mg}, \mathrm{Al}, \mathrm{Si}, \mathrm{Ca}, \mathrm{Ti}, \mathrm{Mn}, \mathrm{Fe}, \mathrm{Cu}, \mathrm{Zn}, \mathrm{Y}, \mathrm{Mo}, \mathrm{Sn}, \mathrm{La}, \mathrm{Ce}, \mathrm{Pr}, \mathrm{Nd}, \mathrm{Sm}$, $\mathrm{Eu}, \mathrm{Gd}, \mathrm{Tb}, \mathrm{Dy}, \mathrm{Ho}, \mathrm{Er}, \mathrm{Tm}, \mathrm{Yb}, \mathrm{Lu}, \mathrm{W}$, and $\mathrm{Pb}$. The off-line data processing was performed using the ICPMSDataCal program [43]. Trace element compositions were calibrated against multiple-references materials without applying internal standardization. The sum of all element concentrations, expressed as oxides according to their oxidation states, is normalized to be $100 \mathrm{wt} \%$ [43].

\section{Results}

\subsection{Major Element Geochemistry}

The major element compositions of the garnets from the Xianghualing skarn Sn deposit are summarized in Table 1, and a full list of the data are given in Table S1 in Supplementary Materials. The three analyzed garnet samples share similar compositions (Table 1). The results indicate that the main components of the Xianghualing garnets are $\mathrm{SiO}_{2}, \mathrm{CaO}, \mathrm{Al}_{2} \mathrm{O}_{3}$, and $\mathrm{Fe}_{2} \mathrm{O}_{3}{ }^{\mathrm{T}}$, and the average concentrations are $38.31 \mathrm{wt} \%$ (range 37.19-39.34 wt \%) for $\mathrm{SiO}_{2}, 31.82 \mathrm{wt} \%\left(30.73-32.98 \mathrm{wt} \%\right.$ ) for $\mathrm{Al}_{2} \mathrm{O}_{3}$, $15.39 \mathrm{wt} \%$ (14.04-16.85 wt \%) for $\mathrm{Al}_{2} \mathrm{O}_{3}$, and $11.70 \mathrm{wt} \%$ (9.43-13.30 wt \%) for $\mathrm{Fe}_{2} \mathrm{O}_{3}$, respectively, with lower amounts of $\mathrm{MnO}$ (average $1.43 \mathrm{wt} \%$ ), $\mathrm{TiO}_{2}$ (average $0.30 \mathrm{wt} \%$ ), and $\mathrm{MgO}$ (average $0.12 \mathrm{wt} \%$ ).

The data show that the garnets from the Xianghualing deposit generally form from a grossular-andradite solid solution. They are Al-rich and dominated by grossular (60.59-70.75 mol \%) and less andradite (18.91-29.76 mol \%), with minor amounts of spessartine, pyrope, and almandine accounting for less than $5.5 \mathrm{~mol} \%$ of the total (Table 1; Figure 4). In general, the contents of grossular and andradite are negatively correlated, but there is no obvious compositional zoning from the core to the rim of an individual garnet grain, although in some grains there are narrow rims surrounding the cores based on the mapping results (Figure 5). The Xianghualing garnets are similar to other skarn $\mathrm{Sn}$ deposits worldwide in composition [44] as shown in Figure 4.

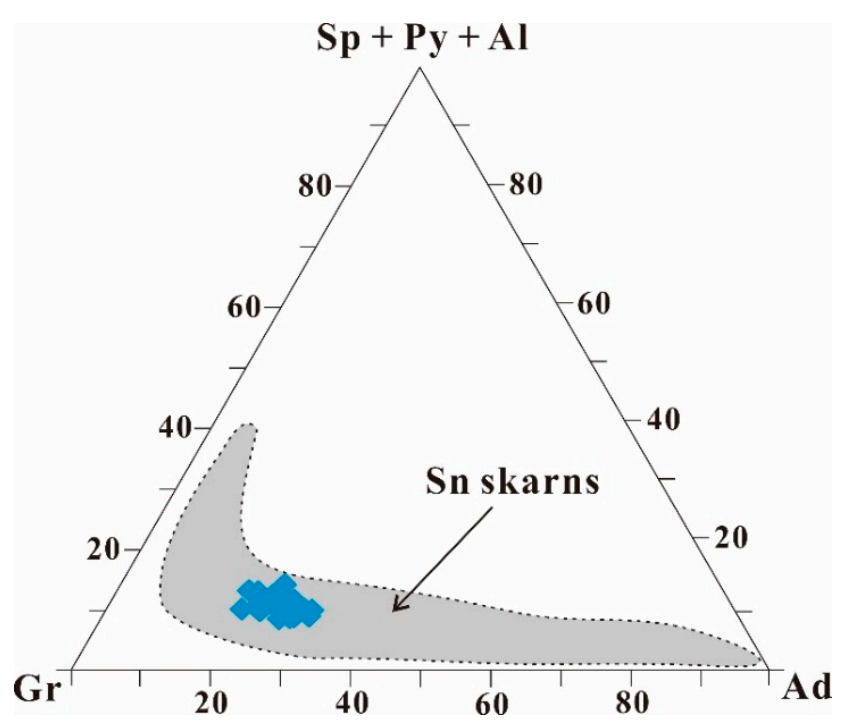

Figure 4. Ternary diagram summarizing garnet compositions in the Xianghualing skarn Sn deposit. Dashed area indicates the garnet composition ranges for skarn Sn deposits worldwide [44]. Abbreviations: $\mathrm{Ad}=$ andradite; $\mathrm{Gr}=$ grossular; $\mathrm{Sp}=$ spessartine; $\mathrm{Py}=$ pyrope and $\mathrm{Al}=$ almandine. 


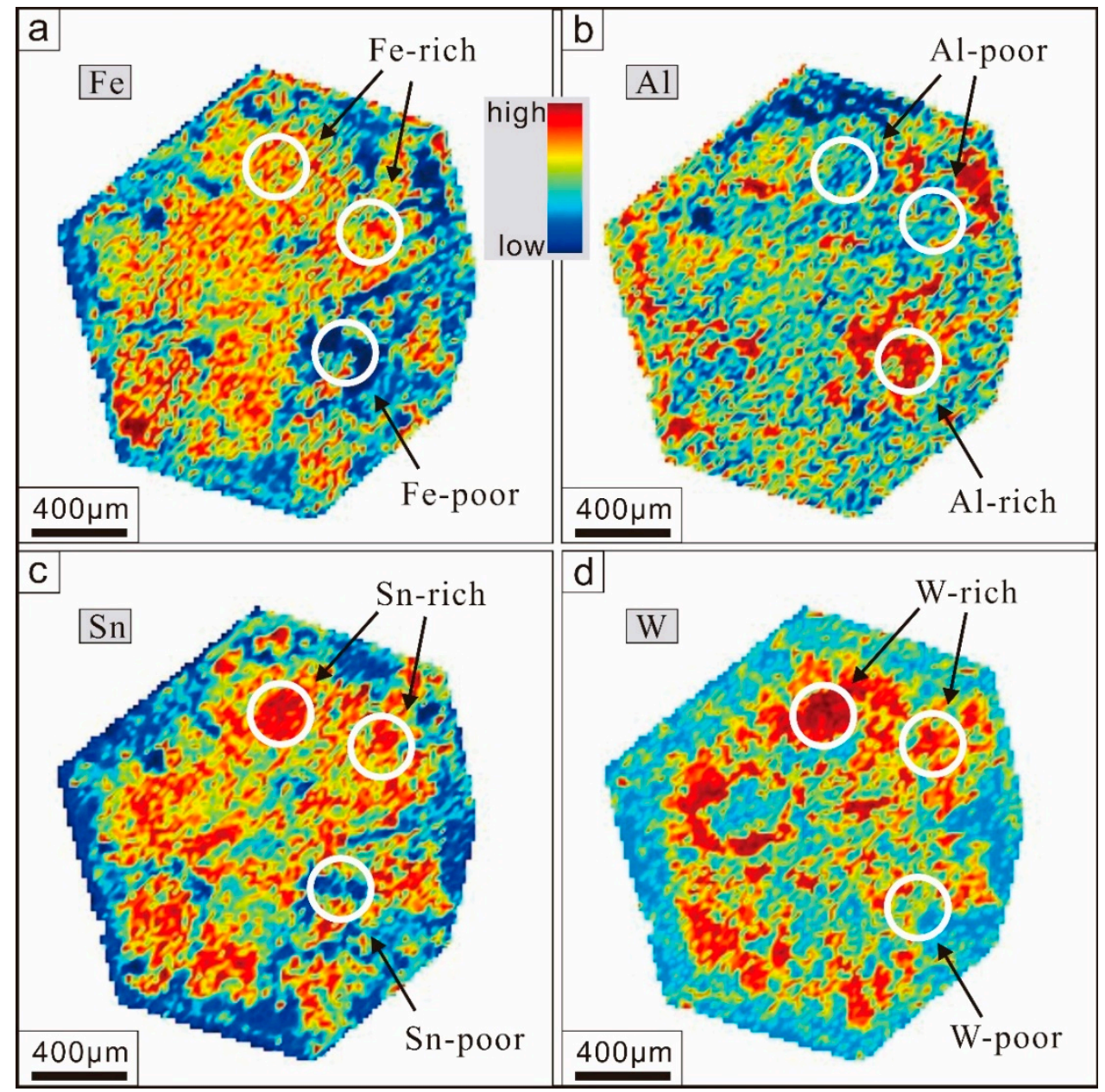

Figure 5. LA-ICP-MS element mapping results of (a) $\mathrm{Fe},(\mathbf{b}) \mathrm{Al}$, (c) $\mathrm{Sn}$, and (d) W for a garnet crystal in Xianghualing.

Table 1. Summary of the major element compositions (in wt \%) of the Xianghualing garnet.

\begin{tabular}{|c|c|c|c|c|c|c|c|c|c|}
\hline \multirow{2}{*}{ Sample } & \multicolumn{3}{|c|}{ XHL-1 $(n=7)$} & \multicolumn{3}{|c|}{ XHL-2 (n = 10) } & \multicolumn{3}{|c|}{ XHL-3 (n = 11) } \\
\hline & Maximum & Minimum & Average & Maximum & Minimum & Average & Maximum & Minimum & Average \\
\hline $\mathrm{MgO}$ & 0.12 & 0.09 & 0.11 & 0.12 & 0.09 & 0.11 & 0.18 & 0.09 & 0.14 \\
\hline $\mathrm{SiO}_{2}$ & 39.34 & 37.89 & 38.58 & 38.25 & 37.19 & 37.80 & 39.11 & 37.96 & 38.61 \\
\hline $\mathrm{CaO}$ & 32.22 & 31.71 & 31.93 & 31.77 & 30.73 & 31.32 & 32.98 & 31.30 & 32.21 \\
\hline $\mathrm{TiO}_{2}$ & 0.55 & 0.36 & 0.49 & 0.27 & 0.09 & 0.20 & 0.64 & 0.12 & 0.27 \\
\hline Total & 99.35 & 98.98 & 99.14 & 99.16 & 98.91 & 98.99 & 99.37 & 98.95 & 99.1 \\
\hline $\mathrm{Mg}$ & 0.01 & 0.01 & 0.01 & 0.01 & 0.01 & 0.01 & 0.02 & 0.01 & 0.02 \\
\hline $\mathrm{Al}$ & 1.46 & 1.36 & 1.41 & 1.56 & 1.40 & 1.50 & 1.47 & 1.30 & 1.37 \\
\hline $\mathrm{Si}$ & 3.07 & 2.97 & 3.03 & 3.00 & 2.92 & 2.97 & 3.08 & 2.99 & 3.03 \\
\hline $\mathrm{Ca}$ & 2.71 & 2.67 & 2.68 & 2.67 & 2.58 & 2.63 & 2.77 & 2.64 & 2.71 \\
\hline $\mathrm{Ti}$ & 0.03 & 0.02 & 0.03 & 0.02 & 0.01 & 0.01 & 0.04 & 0.01 & 0.02 \\
\hline $\mathrm{Gr}$ & 63.96 & 60.71 & 62.23 & 65.13 & 58.68 & 62.6 & 67.42 & 57.78 & 60.99 \\
\hline $\mathrm{Sp}+\mathrm{Py}+\mathrm{Al}$ & 4.68 & 4.37 & 4.56 & 5.11 & 4.48 & 4.75 & 5.29 & 4.43 & 4.81 \\
\hline
\end{tabular}

Note: All the calculations were based on 12 oxygens. Abbreviations: $\mathrm{Ad}=$ andradite; $\mathrm{Gr}=$ grossular; $\mathrm{Sp}=$ spessartine; $\mathrm{Py}=$ pyrope and $\mathrm{Al}=$ almandine . 


\subsection{Trace Element Geochemistry}

The concentrations of trace elements and rare earth elements of the garnets from the Xianghualing skarn Sn deposit are summarized in Table 2 and listed in Table S1. The three garnet samples show little compositional variations. All garnets contain very low concentrations of $\mathrm{Cu}(<0.31 \mathrm{ppm})$, $\mathrm{Mo}(<0.46 \mathrm{ppm})$, and $\mathrm{Pb}(<5.50 \mathrm{ppm})$, but have higher and variable Sn concentrations from 2314 to $5766 \mathrm{ppm}$ (4295 ppm on average). The concentrations of W vary from 0.22 to $30.0 \mathrm{ppm}, \mathrm{Zn}$ from 7.95 to $12.6 \mathrm{ppm}$, and $\mathrm{Pb}$ from 0 to $0.55 \mathrm{ppm}$.

The rare earth elements (REEs) concentrations of the Xianghualing garnets are all very low. Among them, the average $\mathrm{Nd}, \mathrm{Sm}, \mathrm{Gd}, \mathrm{Dy}, \mathrm{Er}$, and $\mathrm{Yb}$ contents are generally higher than $1 \mathrm{ppm}$, whereas the concentrations of all the remaining REE elements (including $\mathrm{La}, \mathrm{Ce}, \mathrm{Pr}, \mathrm{Eu}, \mathrm{Tb}, \mathrm{Ho}, \mathrm{Tm}$, and $\mathrm{Lu}$ ) are lower than 1 ppm. The $\sum$ REE abundances in garnets range from 6.97 to $30.2 \mathrm{ppm}$, with an average of $14.7 \mathrm{ppm}$. Both LREE/HREE and $(\mathrm{La} / \mathrm{Yb})_{\mathrm{N}}$ ratios are generally lower than 1, ranging from 0.01 to 0.75 and from 0 to 0.04 , respectively (Table 2). The garnets display obvious negative Eu anomalies (Eu/Eu* of $0.15-0.79)$, except for one spot that has a Eu/Eu* of 2.37. Similarly, Ce also shows negative anomalies $\left(\mathrm{Ce} / \mathrm{Ce}^{*}=0-0.71\right)$.

Table 2. Summary of the compositions (in $\mathrm{ppm}$ ) for trace and rare earth elements of the Xianghualing garnet.

\begin{tabular}{|c|c|c|c|c|c|c|c|c|c|}
\hline \multirow{2}{*}{ Sample } & \multicolumn{3}{|c|}{ XHL-1 (n= 7) } & \multicolumn{3}{|c|}{ XHL-2 $(n=10)$} & \multicolumn{3}{|c|}{$X H L-3(n=11)$} \\
\hline & Maximum & Minimum & Average & Maximum & Minimum & Average & Maximum & Minimum & Average \\
\hline $\mathrm{Cu}$ & 0.31 & 0 & 0.12 & 0.14 & 0 & 0.06 & 0.23 & 0 & 0.07 \\
\hline $\mathrm{Zn}$ & 12.47 & 7.95 & 10.38 & 12.56 & 9.99 & 11 & 12.24 & 9.15 & 10.76 \\
\hline Mo & 0.25 & 0 & 0.15 & 0.46 & 0.01 & 0.20 & 0.28 & 0.08 & 0.19 \\
\hline Sn & 5228 & 2314 & 3924 & 5766 & 3790 & 5037 & 5706 & 2404 & 3856 \\
\hline $\mathrm{W}$ & 28.2 & 0.45 & 10.9 & 29.99 & 1.15 & 18.89 & 23.09 & 0.22 & 4.89 \\
\hline $\mathrm{Pb}$ & 2.11 & 0 & 0.42 & 0.78 & 0 & 0.11 & 5.50 & 0.17 & 1.68 \\
\hline $\mathrm{La}$ & 0.08 & 0.02 & 0.04 & 0.04 & 0.01 & 0.02 & 0.04 & 0 & 0.01 \\
\hline $\mathrm{Ce}$ & 0.45 & 0.34 & 0.40 & 0.55 & 0.30 & 0.42 & 0.41 & 0 & 0.14 \\
\hline $\operatorname{Pr}$ & 0.25 & 0.18 & 0.20 & 0.30 & 0.15 & 0.20 & 0.26 & 0 & 0.08 \\
\hline $\mathrm{Nd}$ & 3.46 & 1.96 & 2.69 & 3.16 & 1.80 & 2.61 & 3.12 & 0 & 1.02 \\
\hline $\mathrm{Sm}$ & 3.00 & 2.04 & 2.47 & 3.70 & 1.60 & 2.66 & 2.85 & 0 & 1.11 \\
\hline $\mathrm{Eu}$ & 0.62 & 0.26 & 0.39 & 0.74 & 0.34 & 0.52 & 0.59 & 0.02 & 0.22 \\
\hline $\mathrm{Gd}$ & 3.88 & 2.00 & 2.59 & 5.76 & 1.24 & 3.21 & 3.93 & 0.08 & 1.40 \\
\hline $\mathrm{Tb}$ & 0.50 & 0.32 & 0.42 & 1.14 & 0.13 & 0.57 & 0.62 & 0.07 & 0.29 \\
\hline Dy & 2.93 & 1.78 & 2.35 & 6.79 & 0.46 & 3.03 & 3.32 & 1.02 & 1.96 \\
\hline Ho & 0.59 & 0.35 & 0.47 & 1.37 & 0.06 & 0.58 & 0.75 & 0.33 & 0.50 \\
\hline Er & 1.80 & 0.98 & 1.37 & 3.63 & 0.03 & 1.48 & 2.08 & 0.82 & 1.61 \\
\hline $\mathrm{Tm}$ & 0.34 & 0.13 & 0.22 & 0.50 & 0.01 & 0.19 & 0.41 & 0.13 & 0.30 \\
\hline $\mathrm{Yb}$ & 2.17 & 1.14 & 1.78 & 3.10 & 0 & 1.24 & 3.68 & 0.67 & 2.42 \\
\hline $\mathrm{Lu}$ & 0.32 & 0.19 & 0.27 & 0.30 & 0 & 0.13 & 0.62 & 0.06 & 0.41 \\
\hline $\mathrm{Y}$ & 15.66 & 10.50 & 13.33 & 37.24 & 1.33 & 15.35 & 17.96 & 9.23 & 13.39 \\
\hline$\Sigma \mathrm{REE}$ & 17.24 & 13.73 & 15.66 & 30.19 & 7.12 & 16.84 & 19.28 & 6.97 & 11.46 \\
\hline ¿LREE & 7.75 & 4.94 & 6.19 & 8.08 & 4.27 & 6.42 & 7.21 & 0.06 & 2.57 \\
\hline$\Sigma$ HREE & 10.29 & 8.26 & 12.53 & 22.58 & 1.93 & 10.42 & 12.07 & 6.87 & 8.89 \\
\hline$\Sigma$ LREE/ $/$ HREE & 0.75 & 0.6 & 0.49 & 0.36 & 2.22 & 0.62 & 0.6 & 0.01 & 0.29 \\
\hline$\delta \mathrm{Eu}$ & 0.56 & 0.34 & 0.46 & 0.79 & 0.35 & 0.58 & 2.37 & 0.15 & 0.61 \\
\hline$\delta \mathrm{Ce}$ & 0.69 & 0.43 & 0.57 & 0.72 & 0.51 & 0.61 & 2.48 & 0 & 0.56 \\
\hline $\mathrm{La}_{\mathrm{N}} / \mathrm{Yb}_{\mathrm{N}}$ & 0.03 & 0.01 & 0.02 & 0.04 & 0 & 0.01 & 0.03 & 0 & 0.01 \\
\hline
\end{tabular}

\section{Discussion}

\subsection{REE Patterns in Garnet and Their Significance}

The REE enrichments in skarn minerals like garnet are controlled by several factors, including the REE concentrations in the source magmas and/or wallrocks (typically carbonate), the REE concentrations in the hydrothermal fluids forming the skarns, and the mobility of REEs (i.e., their ability to be released during hydrothermal alteration) [45,46]. In addition, several physicochemical parameters of the hydrothermal fluids responsible for the skarn formation, including salinity, $\mathrm{pH}, f_{\mathrm{O} 2}, \mathrm{X}_{\mathrm{CO} 2}$, pressure, and temperature, have also been suggested to be critical in the REE incorporation into garnets [47-49]. As shown in Figure 6, the chondrite-normalized REE patterns [50] of the garnets from the Xianghualing 
skarn Sn deposit indicate that the garnets are generally enriched in heavy REE (HREE) relative to light REE (LREE), with pronounced negative Eu anomalies. This is also similar to the garnets from many other Sn-bearing skarn deposits in China, such as the Shizhuyuan skarn W-Sn-Mo-Bi deposit [51,52] and the Jinchuantang skarn Sn-Bi deposit [53] in Hunan Province, the Gejiu skarn Sn deposit in Yunnan Province [54], and the Huanggangliang skarn Sn-Fe deposit in Inner Mongolia [55]. As documented in previous studies, such REE patterns indicate that the incorporation of the REEs into garnets was controlled by crystal chemistry through isomorphic substitution [19,53], and that the HREEs with smaller ionic radii are more compatible to be accommodated in the octahedral coordination site of garnet lattice than the LREEs with larger ionic radii [56,57]. The REEs in garnets of the Xianghualing deposit display similar patterns and therefore are believed to be controlled by the crystal chemical structure.

The obviously negative Eu anomalies of the garnets from the Xianghualing deposit imply a relatively low oxygen fugacity of the mineralizing fluid. Under reduced conditions, unlike other REEs that only have +3 valence (and +4 valence for $\mathrm{Ce}$ ), Eu can also occur as $\mathrm{Eu}^{2+}$. The reduced $\mathrm{Eu}^{2+}$ $(1.25 \AA)$ can less preferentially substitute for $\mathrm{Ca}^{2+}(1.12 \AA)$ than the oxidized cation $\mathrm{Eu}^{3+}(1.07 \AA)$ in the octahedral position $[58,59]$. As a consequence, negative Eu anomalies would be generated in a reduced environment. On the contrary, many $\mathrm{Cu}$-rich skarn deposits formed in oxidized conditions [1,60], and as a result, they show typical positive Eu anomalies (Figure 7). To sum up, the negative Eu anomalies of the Xianghualing garnets indicate a reduced condition of the magmatic systems and their exsolved hydrothermal fluids. This is consistent with many other hydrothermal Sn deposits in China and worldwide, which are commonly related to highly reduced granitic system [1,60,61].

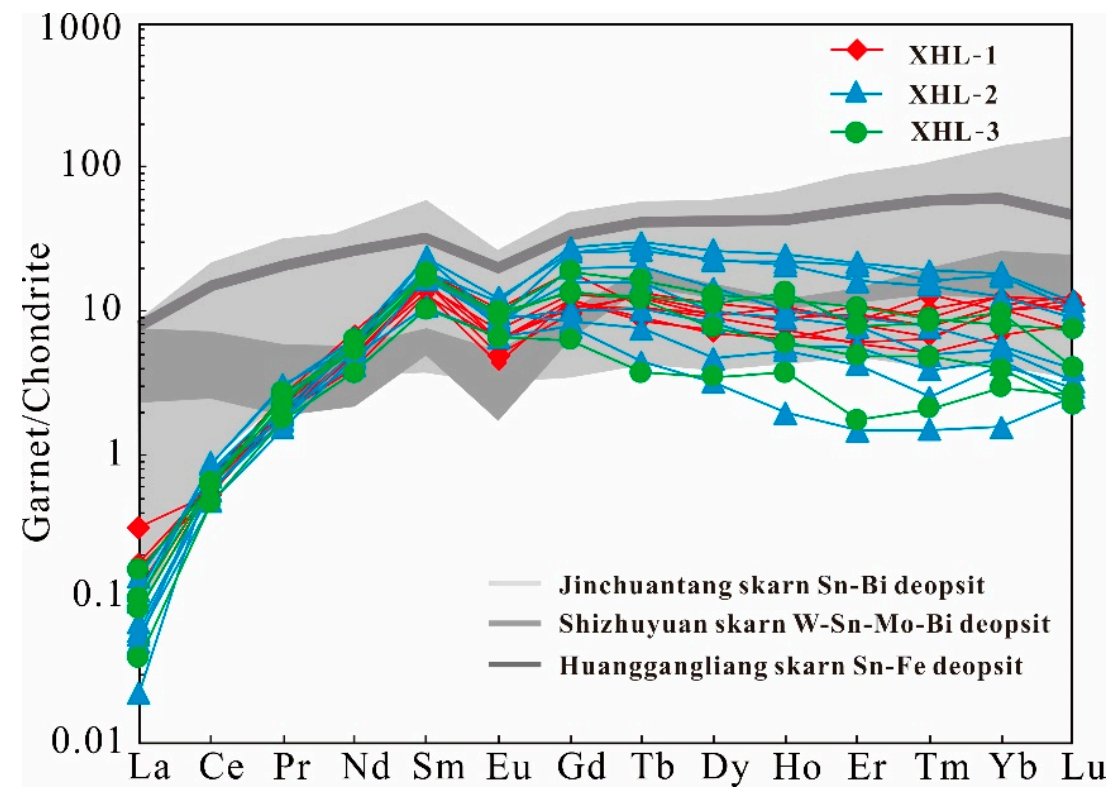

Figure 6. Chondrite-normalized REE patterns of the garnets from Xianghualing. Dashed area indicates the Chondrite-normalized REE partition curves of the garnets from other Sn-rich deposits including Jinchuantang [53], Shizhuyuan [51] and Huanggangliang [55], which have been shown here for comparison. All data were normalized to the $\mathrm{C} 1$ chondrite values [50]. 


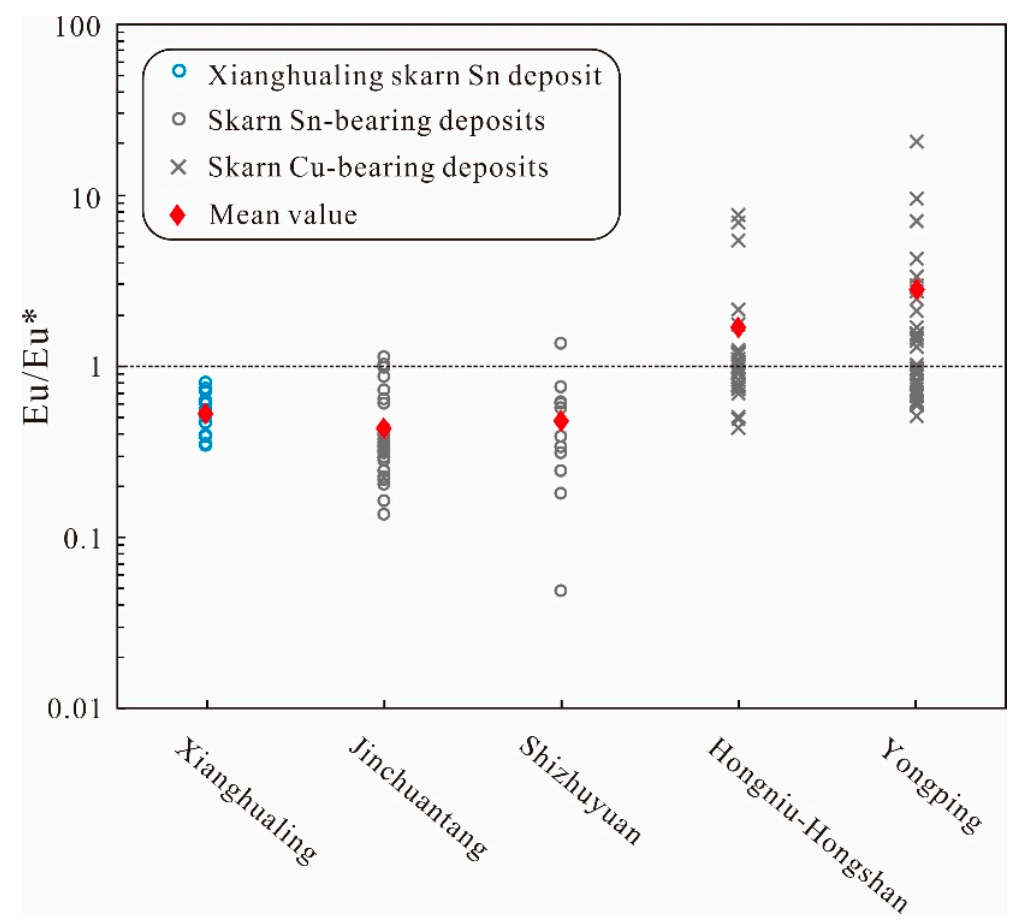

Figure 7. Garnet $\mathrm{Eu} / \mathrm{Eu}^{*}$ ratios of Xianghualing and several other skarn deposits. Note: The compiled skarn Sn-bearing deposits include Jinchuantang skarn Sn-Bi deposit [53] and Shizhuyuan skarn W-Sn-Mo-Bi deposit [51]. The Cu skarns include Hongniu-Hongshan [19] and Yongping [62] skarn $\mathrm{Cu}$ deposits.

\subsection{Substitution of Sn into Garnet}

Garnet has a general chemical formula $\mathrm{X}_{3} \mathrm{Y}_{2} \mathrm{Z}_{3} \mathrm{O}_{12}$, where $\mathrm{X}$ represents divalent cations in eightfold coordination, $\mathrm{Y}$ represents trivalent cations in octahedral coordination, and $\mathrm{Z}$ is dominantly $\mathrm{Si}$ in tetrahedral coordination [63,64]. According to the results listed in Table 1, the Xianghualing garnet belongs to the series of grossular-andradite solid solution. It can be inferred that the $\mathrm{X}$ position of the eightfold coordination is mainly $\mathrm{Ca}^{2+}$, containing a small amount of $\mathrm{Fe}^{2+}, \mathrm{Mn}^{2+}, \mathrm{Mg}^{2+}$, and other divalent cations (e.g., REEs), and the $\mathrm{Y}$ position is mainly occupied by $\mathrm{Fe}^{3+}$ and $\mathrm{Al}^{3+}$.

The incorporation of trace elements into garnet crystals, like the REEs proposed above, is essentially controlled by crystal chemistry [65]. According to the Goldschmidt's first rule, the ionic radius and charge mismatch between the host cation and its substituent, at a given site, exert the principal control on substitution mechanisms $[19,60]$. The ionic radius of $\mathrm{Sn}^{4+}$ is $0.69 \AA$, which is close in size to $\mathrm{Fe}^{3+}$ $(0.67 \AA)$ in the octahedral site of garnet [60], making it possible for $\mathrm{Sn}^{4+}$ to substitute $\mathrm{Fe}^{3+}$. In this study, there is a generally positive correlation between the content of $\mathrm{Fe}$ and $\mathrm{Sn}$ in Xianghualing garnets based on the mapping results (Figure 5). This suggests that $\mathrm{Sn}^{4+}$ is likely to occupy the octahedral sites of garnet through replacement of $\mathrm{Fe}^{3+}$. The possible mechanism for such a substitution (Equation (1)) could be:

$$
3 \mathrm{Sn}^{4+}+\square=4 \mathrm{Fe}^{3+}
$$

Here $\square$ is a divalent cations-site vacancy in the octahedral site [66].

It should be noted that the above substitution of $\mathrm{Sn}^{4+}$ for $\mathrm{Fe}^{3+}$ requires not only a modification of the crystal structure, but also charge balance. The charge difference between quadrivalent $\mathrm{Sn}$ and trivalent Fe makes it necessary to get a compensatory mechanism to maintain charge balance. As a result, two other cosubstitution mechanisms (Equations (2) and (3)) have also been proposed [52,67-69]:

$$
\begin{gathered}
\mathrm{Sn}^{4+}+\mathrm{Fe}^{2+}=2 \mathrm{Fe}^{3+} \\
\mathrm{Sn}^{4+}+\mathrm{Mg}^{2+}=2 \mathrm{Fe}^{3+}
\end{gathered}
$$


As shown in Figure 8a, however, the atoms of divalent iron and the content of Sn do not show any positive correlations, indicating that the cosubstitution (Equation (2)) might be weak, although it cannot be fully ruled out. As for the Mg-Sn cosubstitution (Equation (3)), because of the relatively low $\mathrm{Mg}$ concentrations of the garnets in Xianghualing (Table 1) and the poor correlations between the $\mathrm{Mg}^{2+}$ and Sn content (Figure 8b), it is also unlikely to be the major diadochic substitution mechanism.
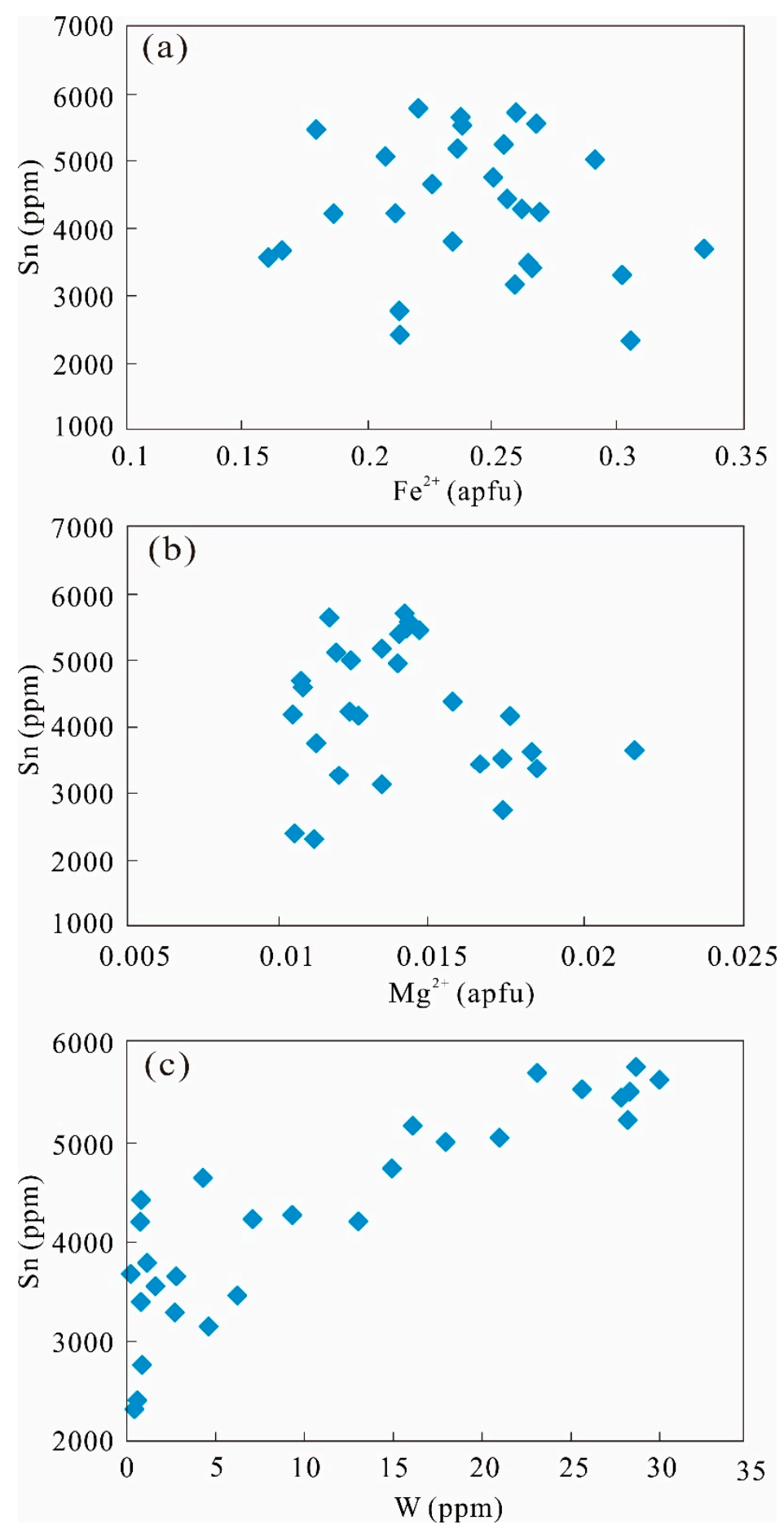

Figure 8. Geochemical compositions of garnets from Xianghualing. Plots of (a) Sn (ppm) vs. $\mathrm{Fe}^{2+}$ (apfu), (b) Sn (ppm) vs. $\mathrm{Mg}^{2+}(\mathrm{apfu})$, and (c) Sn (ppm) vs. W (ppm). apfu = atoms per formula unit.

Based on the above observations, it is concluded that the incorporation of Sn into prograde skarn garnets in the Xianghualing deposit are mainly through the substitution $3 \mathrm{Sn}^{4+}+\square=4 \mathrm{Fe}^{3+}$. 
Interestingly, as shown in the mapping results (Figure 5), the concentrations of Sn and W in the garnets are also positively correlated. This has also been confirmed by the LA-ICP-MS analysis results as shown in Figure 8c. This implies that the mechanism for W substitution into the garnet may be similar to that of Sn.

It should be noted that the ability of Sn substitution into garnet is controlled by the Sn contents in hydrothermal fluids and the partitioning coefficient between fluids and garnet. The partitioning coefficient is further related to the Sn availability in the hydrothermal system; the mineral composition into which Sn substitutes [16,70]; as well as the fluid temperature, $\mathrm{pH}$, salinity, pressure, and the chlorine and possibly fluorine contents [70-72]. Based on the microthermometric data for primary fluid inclusions from the different Sn-bearing deposits [73-76], including Xi'ao skarn Cu-Sn deposit, Huanggang skarn Fe-Sn deposit, Shizhuyuan skarn W-Sn deposit and Xianghualing skarn Sn deposit, it can be concluded that they have similar formation temperatures of garnet (mainly $400-500{ }^{\circ} \mathrm{C}$ ), salinities (mainly around $10 \mathrm{wt} \% \mathrm{NaCl}$ equivalent) and pressures (around $500 \mathrm{bars}$ ). Hence, it is reasonable to conclude that these parameters of the Sn-bearing hydrothermal fluids have similar effects on the partitioning coefficient of Sn between fluids and garnets. Therefore, the ability of Sn substitution into garnet largely depends on the concentrations of $\mathrm{Sn}$ in the fluids.

\subsection{Exploration Implications}

The garnets of the Xianghualing deposit contain relatively high Sn concentrations (>2000 ppm), especially for the sample XHL-2-2, which reaches up to $>5700 \mathrm{ppm}$ (Table 2). Similarly high Sn concentrations in garnets have also been observed in other skarn $\mathrm{Sn}$ deposits from previous studies. The garnet from a skarn Sn polymetallic deposit in Finland contains up to $1.44 \mathrm{wt} \% \mathrm{SnO}_{2}$ [77]. Also, the content of $\mathrm{SnO}_{2}$ in garnets at Doradilla, New South Wales, Australia is as high as 0.5-3.5 wt \% [68]. The studies on several Sn-bearing skarn deposits in South China (e.g., Yaogangxian, Dachang, Xinlu, Debao, Gejiu, and Shizhuyuan) also show that the contents of $\mathrm{SnO}_{2}$ in garnets are generally in the range of 0.02-2 wt \%, particularly in Gejiu, where the highest value can be up to $5.14 \mathrm{wt} \%$ [51,52]. For garnets from skarn deposits containing both Sn and W, including the Baiganhu skarn W-Sn deposit and the Huangshaping skarn W-Sn deposit, the LA-ICP-MS analysis results show that both are rich in Sn (Figure 9), with a maximum of 4990 ppm and 8364 ppm, respectively [23,65]. Combined with the results of this study, it can be generally concluded that the garnets in Sn-bearing skarn deposits are commonly enriched in Sn. A reasonable explanation given by Zhou et al [23] is that the substitution of $\mathrm{Sn}^{4+}$ for $\mathrm{Fe}^{3+}$ can more readily take place when the hydrothermal fluids responsible for the $\mathrm{Sn}$ mineralization contain elevated concentrations of $\mathrm{Sn}$, regardless of other factors, such as redox state, $\mathrm{pH}$, and temperature conditions [23]. As mentioned above, the abundance of Sn in garnet largely depends on the Sn concentrations in the hydrothermal fluids. Accordingly, the Sn content of garnet can be used to evaluate the potential of Sn mineralization in a skarn system.

As for the two skarn deposits containing both economic Sn and W (Baiganhu and Huangshaping), the $\mathrm{W}$ concentrations in garnets are also very high, although variable: the range is between $<1$ to 2092 ppm [23,65]. For the Weondong skarn W deposit (without Sn) from South Korea [78], the garnet W concentrations (5-760 ppm) are as high as in these Sn-W skarn deposits, and significantly higher than the Xianghualing skarn Sn deposit (Figure 9). However, the Sn concentrations (32-228 ppm) in Weondong garnets are lower than these Sn-bearing skarn deposits (Figure 8). These observations indicate that skarn Sn deposits commonly contain Sn-rich, but W-poor garnets, whereas skarn W deposits commonly contain W-rich, but Sn-poor garnets; for skarn deposits containing both Sn and W, the garnets may be enriched in both the two ore-forming elements. This might be applied in skarn occurrences where exploration is ongoing to reveal their Sn and/or W mineralization potential. 


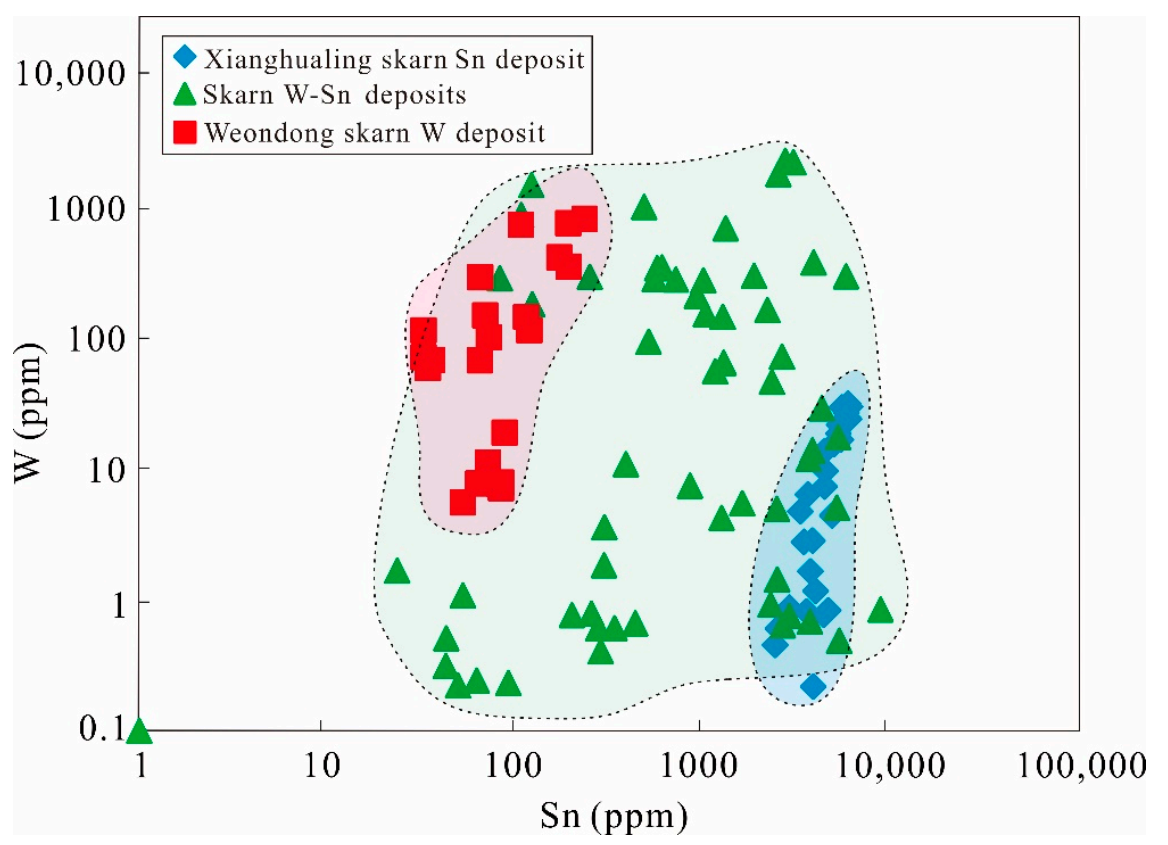

Figure 9. Binary plots of Sn vs. W concentrations of garnets from different deposits. Note: skarn W-Sn deposits include Baiganhu [23] and Huangshaping [65]. The data of the Weondong skarn W deposit are from [78].

\section{Conclusions}

(1) Garnets in the Xianghualing skarn Sn deposit in South China belong to typical grossular-andradite solid solution. They are characterized by HREE enrichment, LREE depletion and negative Eu anomalies, indicative of a reduced magmatic-hydrothermal environment. The enrichment of $\mathrm{Sn}$ in garnet is mainly controlled by the substitution into the $\mathrm{Fe}^{3+}$ octahedral site.

(2) Garnets from skarn Sn deposits like Xianghualing are generally Sn-rich and W-poor, whereas those from skarn W deposits (e.g., Weondong) are W-rich and Sn-poor. Interestingly, the Sn and W concentrations in garnets from skarn Sn-W deposits can both be very high. Such observations are potentially useful in guiding exploration for these skarn occurrences without defined $\mathrm{Sn}$ and/or W resources to evaluate their potentials to form economic Sn and (or) W mineralization.

Supplementary Materials: The following are available online at http://www.mdpi.com/2075-163X/10/5/456/s1, Table S1: Summary of the major element compositions (in wt \%) and trace and rare earth elements compositions (ppm) of the Xianghualing garnets.

Author Contributions: Q.S. designed the project; F.Y., L.L., Q.Z., and W.Y. collected the samples; F.Y., X.N., and K.X. performed the LA-ICP-MS analyses and reduced the data; F.Y. and Q.S. wrote and organized the paper, with a careful discussion and revision by D.R.L. All authors discussed the results and evaluated the data. All authors have read and agreed to the published version of the manuscript.

Funding: This research was financially supported by the National Natural Science Foundation of China (41973043, 41602083), the fund from the Key Laboratory of Deep-Earth Dynamics of Ministry of Natural Resources, the MOST Special Fund from the State Key Laboratory of Geological Processes and Mineral Resources, China University of Geosciences (MSFGPMR201804), and the 111 Project of the Ministry of Science and Technology (BP0719021). DL was supported by a NSERC Discovery grant.

Acknowledgments: We are grateful to Fangyue Wang for his assistance during the analyses. We also thank the three anonymous reviewers and an academic editor for their constructive comments on the manuscript.

Conflicts of Interest: The authors declare no conflict of interest. 


\section{References}

1. Chang, Z.; Shu, Q.; Meinert, L.D. Skarn deposits of China. Soc. Econ. Geol. Spec. Publ. 2019, 22, 189-234.

2. Xu, Q.D.; Zhang, J.T. Analysis on geological background of metallization and assessment on potential ore-resources in Xianghualing orefield, Hunan. Earth Sci. 1993, 18, 602-611. (In Chinese)

3. Qiu, R.Z.; Deng, J.F.; Cai, Z.Y.; Zhou, S.; Chang, H.L.; Du, S.H. Material sources of granite and ore in Xianghualing multi-metal orefield, Hunan Province. Miner. Depos. 2002, 21, 1017-1020. (In Chinese)

4. Li, C.; Yang, C.M.; Zhong, J.L. Relationship between ore controlling factors and geochemical features in Xianghualing ore field. Miner. Resour. Geol. 2005, 19, 529-532. (In Chinese)

5. Zhong, J.L.; Li, C.P. Geological characteristics and genesis of Xianghualing skarn type tin deposit. Miner. Resour. Geol. 2006, 20, 147-151. (In Chinese)

6. Yuan, S.D.; Peng, J.T.; Li, X.Q.; Peng, Q.L.; Fu, Y.Z.; Shen, N.P.; Zhang, D.L. Carbon, oxygen and strontium isotope geochemistry of calcites from the Xianghualing tin-polymetallic deposit, Hunan Province. Acta Geol. Sin. 2008, 82, 1522-1530. (In Chinese)

7. Zhou, T.; Liu, W.H.; Li, H.; Xu, W.X.; Dai, T.G. Isotope geochemistry of the Xianghualing tin-polymetallic deposit in Hunan Province. Acta Geosci. Sin. 2008, 29, 703-708. (In Chinese)

8. Yu, X.G.; Rao, C.; Wang, W.M.Y.; Lin, X.Q.; Qin, L.Q. Mineralogical behavior and metallogenic process of Sn in the Xianghualing skarn, Hunan Province. Geol. J. China Univ. 2018, 24, 645-657. (In Chinese)

9. Xie, L.; Wang, R.C.; Chen, J.; Zhu, J.C.; Zhang, W.L.; Wang, D.Z.; Yu, A.P. Primary Sn-rich titanite in the Qitianling granite, Hunan Province, southern China: An important type of tin-bearing mineral and its implications for tin exploration. Chin. Sci. Bull. 2008, 53, 3115-3122. (In Chinese)

10. Wang, R.C.; Zhu, J.C.; Zhang, W.L.; Xie, L.; Yu, A.P.; Che, X.D. Ore forming mineralogy of W-Sn granites in the Nanling Range: Concept and case study. Geol. J. China Univ. 2008, 14, 485-495. (In Chinese)

11. Wang, R.C.; Xie, L.; Chen, J.; Yu, A.P.; Wang, L.B.; Lu, J.J.; Zhu, J.C. Titanite as an indicator mineral of tin mineralizing potential of granites in the middle Nanling range. Geol. J. China Univ. 2011, 17, 368-380. (In Chinese)

12. Li, D.F.; Tan, C.Y.; Miao, F.Y.; Liu, Q.F.; Zhang, Y.; Sun, X.M. Initiation of Zn-Pb mineralization in the Pingbao $\mathrm{Pb}-\mathrm{Zn}$ skarn district, South China: Constraints from $\mathrm{U}-\mathrm{Pb}$ dating of grossular-rich garnet. Ore Geol. Rev. 2019, 107, 587-599. [CrossRef]

13. Shu, Q.; Chang, Z.; Hammerli, J.; Lai, Y.; Huizenga, J.M. Composition and evolution of fluids forming the Baiyinnuo'er $\mathrm{Zn}-\mathrm{Pb}$ skarn deposit, northeastern China: Insights from laser ablation ICP-MS study of fluid inclusions. Econ. Geol. 2017, 112, 1441-1460. [CrossRef]

14. Shu, Q.; Lai, Y.; Sun, Y.; Wang, C.; Meng, S. Ore genesis and hydrothermal evolution of the Baiyinnuo'er zinc-lead skarn deposit, northeast China: Evidence from isotopes $(\mathrm{S}, \mathrm{Pb})$ and fluid inclusions. Econ. Geol. 2013, 108, 835-860. [CrossRef]

15. Taylor, B.E.; Liou, J.G. The low-temperature stability of andradite in C-O-H fluids. Am. Mineral. 1978, 63, 378-393.

16. Fei, X.H.; Zhang, Z.C.; Cheng, Z.G.; Santosh, M. Factors controlling the crystal morphology and chemistry of garnet in skarn deposits: A case study from the Cuihongshan polymetallic deposit, Lesser Xing'an Range, NE China. Am. Mineral. 2019, 104, 1455-1468. [CrossRef]

17. Jia, R.X.; Fang, W.X. Geochemical characteristics and their significance of garnets from Gejiu Sn polymetallic deposit of Yunnan. J. Earth Sci. Environ. 2016, 38, 578-586. (In Chinese)

18. Zhou, Z.H.; Liu, H.W.; Chang, G.X.; Lü, L.S.; Li, T.; Yang, Y.J.; Zhang, R.J.; Ji, X.H. Mineralogical characteristics of skarns in the Huanggang Sn-Fe deposit of Inner Mongolia and their metallogenic indicating significance. Acta Petrol. Mineral. 2011, 30, 97-112. (In Chinese)

19. Peng, H.J.; Zhang, C.Q.; Mao, J.W.; Santosh, M.; Zhou, Y.M.; Hou, L. Garnets in porphyry-skarn systems: A LA-ICP-MS, fluid inclusion, and stable isotope study of garnets from the Hongniu-Hongshan copper deposit, Zhongdian area, NW Yunnan Province, China. J. Asian Earth Sci. 2015, 103, 229-251. [CrossRef]

20. Newberry, P.J. The formation of subcalcic garnet in scheelite-bearing skarns. Can. Mineral. 1983, $21,529-544$.

21. Peng, H.J.; Mao, J.W.; Hou, L.; Shu, Q.H.; Zhang, C.Q.; Liu, H.; Zhou, Y.M. Stable isotope and fluid inclusion constraints on the source and evolution of ore fluids in the Hongniu-Hongshan Cu skarn deposit, Yunnan Province. China. Econ. Geol. 2016, 111, 1369-1396. [CrossRef] 
22. Zhou, Z.H.; Mao, J.W.; Lyckberg, P. Geochronology and isotopic geochemistry of the A-type granites from the Huanggang Sn-Fe deposit, southern Great Hinggan Range, NE China: Implication for their origin and tectonic setting. J. Asian Earth Sci. 2012, 49, 272-286. [CrossRef]

23. Zhou, J.; Feng, C.; Li, D. Geochemistry of the garnets in the Baiganhu W-Sn orefield, NW China. Ore Geol. Rev. 2017, 82, 70-92. [CrossRef]

24. Fan, X.J.; Wang, X.D.; Lü, X.B.; Wei, W.; Chen, W. Garnet composition as an indicator of skarn formation: LA-ICP-MS and EPMA studies on oscillatory zoned garnets from the Haobugao skarn deposit, Inner Mongolia, China. Geol. J. 2018, 54, 1976-1992. [CrossRef]

25. Meinert, L.D. Application of skarn deposit zonation models to mineral exploration. Explor. Min. Geol. 1997, $6,185-208$.

26. Somarin, A.K. Garnet composition as an indicator of $\mathrm{Cu}$ mineralization: Evidence from skarn deposits of NW Iran. J. Geochem. Explor. 2004, 81, 47-57. [CrossRef]

27. Wang, C.M.; Zhang, L.; Tang, H.S.; Chen, H.Y.; Li, X.L.; Zheng, Y.; Li, D.F.; Fang, J.; Dong, H.L.; Qu, X. Genesis of the Kaladawan Fe-Mo ore field in Altyn, Xinjiang, China: Constraints from mineralogy and geochemistry. Ore Geol. Rev. 2017, 81, 587-601. [CrossRef]

28. Liu, J.P.; Rong, Y.N.; Zhang, S.G.; Liu, Z.F.; Chen, W.K. Indium mineralization in the Xianghualing Sn-polymetallic orefield in southern Hunan, Southern China. Minerals 2017, 7, 173. [CrossRef]

29. Li, H.; Wu, J.H.; Evans, N.J.; Jiang, W.C.; Zhou, Z.K. Zircon geochronology and geochemistry of the Xianghualing A-type granitic rocks: Insights into multi-stage Sn-polymetallic mineralization in South China. Lithos 2018, 312-313, 1-20. [CrossRef]

30. Wu, J.H.; Li, H.; Algeo, T.J.; Jiang, W.C.; Zhou, Z.K. Genesis of the Xianghualing Sn-Pb-Zn deposit, South China: A multi-method zircon study. Ore Geol. Rev. 2018, 102, 220-239. [CrossRef]

31. Zhang, R.Q.; Lu, J.J.; Wang, R.C.; Yang, P.; Zhu, J.C.; Yao, Y.; Gao, J.F.; Li, C.; Lei, Z.H.; Zhang, W.L.; et al. Constraints of in situ zircon and cassiterite $\mathrm{U}-\mathrm{Pb}$, molybdenite Re-Os and muscovite ${ }^{40} \mathrm{Ar}-{ }^{39} \mathrm{Ar}$ ages on multiple generations of granitic magmatism and related W-Sn mineralization in the Wangxianling area, Nanling Range, South China. Ore Geol. Rev. 2015, 65, 1021-1042. [CrossRef]

32. Yuan, S.D.; Mao, J.; Cook, N.J.; Wang, X.D.; Liu, X.F.; Yuan, Y.B. A Late Cretaceous tin metallogenic event in Nanling W-Sn metallogenic province: Constraints from U-Pb, Ar-Ar geochronology at the Jiepailing Sn-Be-F deposit, Hunan, China. Ore Geol. Rev. 2015, 65, 283-293. [CrossRef]

33. Liang, X.Q.; Jiang, Y.; Dong, C.G.; Fu, J.G.; Wang, C.; Zhou, Y. LA-ICP-MS zircon U-Pb and molybdenite Re-Os isotopic dating of the tungsten deposits in the Dengfuxian W-Sn orefield, eastern Hunan Province, South China, and their geological implications. Acta Geol. Sin.-Engl. Ed. 2014, 2, 99-100. [CrossRef]

34. Liang, X.Q.; Dong, C.G.; Jiang, Y.; Wu, S.C.; Zhou, Y.; Zhu, H.F.; Fu, J.G.; Wang, C.; Shan, Y.H. Zircon U-Pb, molybdenite Re-Os and muscovite ${ }^{40} \mathrm{Ar}^{-39} \mathrm{Ar}$ isotopic dating of the Xitian W-Sn polymetallic deposit, Eastern Hunan Province, South China and its geological significance. Ore Geol. Rev. 2016, 78, 85-100. [CrossRef]

35. Yuan, S.D.; Peng, J.T.; Hu, R.Z.; Li, H.M.; Shen, N.P.; Zhang, D.L. A precise U-Pb age on cassiterite from the Xianghualing tin-polymetallic deposit (Hunan, South China). Miner. Depos. 2007, 43, 375-382. [CrossRef]

36. Cai, H.Y. The metallogenic geological setting and approach on ore genesis of Xianghualing tin-polymetallic ore field. Miner. Resour. Geol. 1991, 5, 272-283. (In Chinese)

37. Zhu, J.C.; Wang, R.C.; Lu, J.J.; Zhang, H.; Zhang, W.L.; Xie, L.; Zhang, R.Q. Fractionation, evolution, petrogenesis and mineralization of Laiziling granite pluton, Southern Hunan Province. Geol. J. China Univ. 2011, 17, 381-392. (In Chinese)

38. Yuan, S.D.; Peng, J.T.; Shen, N.P.; Hu, R.Z.; Dai, T.M. ${ }^{40} \mathrm{Ar}-{ }^{39}$ Ar isotopic dating of the Xianghualing Sn-polymetallic Orefield in Southern Hunan, China and its geological implications. Acta Geol. Sin.-Engl. Ed. 2007, 81, 278-286.

39. Zhang, D.Q.; Wang, L.H. Metallogenic zoning and genesis of the Xianghualing ore field. Miner. Depos. 1988, 7, 33-42. (In Chinese)

40. Yang, Y.F.; Yu, H.Y.; Zhang, L.J.; Qin, M.F. REE Characteristics of the green fluorite in Xianghualing, Hunan Province. Mod. Min. 2019, 35, 64-67. (In Chinese)

41. Wang, F.Y.; Ge, C.; Ning, S.Y.; Nie, L.Q.; Zhong, G.X.; White, N.C. A new approach to LA-ICP-MS mapping and application in geology. Acta Petrol. Sin. 2017, 33, 3422-3436. (In Chinese)

42. Raimondo, T.; Payne, J.; Wade, B.; Lanari, P.; Clark, C.; Hand, M. Trace element mapping by LA-ICP-MS: Assessing geochemical mobility in garnet. Contrib. Mineral. Petrol. 2017, 172, 17. [CrossRef] 
43. Liu, Y.S.; Hu, Z.C.; Gao, S.; Günther, D.; Xu, J.; Gao, C.G.; Chen, H.H. In situ analysis of major and trace elements of anhydrous minerals by LA-ICP-MS without applying an internal standard. Chem. Geol. 2008, 257, 34-43. [CrossRef]

44. Meinert, L.D. Skarns and skarn deposits. Geosci. Can. 1992, 19, 145-162.

45. Ranjbar, S.; Tabatabaei Manesh, S.M.; Mackizadeh, M.A.; Tabatabaei, S.H.; Parfenova, O.V. Geochemistry of major and rare earth elements in garnet of the Kal-e Kafi Skarn, Anarak Area, Central Iran: Constraints on processes in a hydrothermal system. Geochem. Int. 2016, 54, 423-438. [CrossRef]

46. Zhao, W.W.; Zhou, M.F.; Williams-Jones, A.E.; Zhao, Z. Constraints on the uptake of REE by scheelite in the Baoshan tungsten skarn deposit, South China. Chem. Geol. 2018, 477, 123-136. [CrossRef]

47. Jiang, S.Y.; Yu, J.M.; Lu, J.J. Trace and rare-earth element geochemistry in tourmaline and cassiterite from the Yunlong tin deposit, Yunnan, China: Implication for migmatitic-hydrothermal fluid evolution and ore genesis. Chem. Geol. 2004, 209, 193-213. [CrossRef]

48. Williams-Jones, A.E.; Migdisov, A.A.; Samson, I.M. Hydrothermal mobilisation of the rare earth elements-A tale of "Ceria" and "Yttria". Elements 2012, 8, 355-360. [CrossRef]

49. Xu, J.; Ciobanu, C.L.; Cook, N.J.; Zheng, Y.Y.; Li, X.F.; Wade, B.P.; Verdugo-Ihl, M.R.; Gao, W.Y.; Zhu, Q.Q. Numerical modelling of rare earth element fractionation trends in garnet: A tool to monitor skarn evolution. Contrib. Mineral. Petrol. 2020, 175, 17. [CrossRef]

50. Pourmand, A.; Dauphas, N.; Ireland, T.J. A novel extraction chromatography and MC-ICP-MS technique for rapid analysis of REE, Sc and Y: Revising CI-chondrite and Post-Archean Australian Shale (PAAS) abundances. Chem. Geol. 2012, 291, 38-54. [CrossRef]

51. Chen, J.; Halls, C.; Stanley, C.J. Rare earth element contents and patterns in major skarn minerals from Shizhuyuan W, Sn, Bi and Mo deposit, South China. Geochem. J. 1992, 26, 147-158. [CrossRef]

52. Chen, J.; Halls, C.; Stanley, C.J. Tin-bearing skarns of South China: Geological setting and mineralogy. Ore Geol. Rev. 1992, 7, 225-248. [CrossRef]

53. Liu, X.F.; Yuan, S.D.; Shuang, Y.; Yuan, Y.B.; Mi, J.R.; Xuan, Y.S. In situ LA-ICP-MS REE analyses of the skarn garnets from the Jinchuantang tin-bismuth deposit in Hunan Province, and their significance. Acta Petrol. Sin. 2014, 30, 163-177. (In Chinese)

54. Han, S.; Huang, Z.X.; Jia, X.Q.; Dong, J.Q. The geochemical characteristics of rare earth elements in skarn and their garnets from Damoshan area, Gejiu district, Yunnan Province. Acta Petrol. Sin. 1993, 9, 192-198. (In Chinese)

55. Wang, L.J.; Wang, J.B.; Wang, Y.W.; Hidehiko, S. REE geochemistry of the Huangguangliang skarn Fe-Sn deposit, Inner Mongolia. Acta Petrol. Sin. 2002, 18, 575-584. (In Chinese)

56. Pride, C.; Muecke, G.K. Rare earth element distributions among coexisting granulite facies minerals, Scourian complex, NW Scotland. Contrib. Mineral. Petrol. 1981, 76, 463-471. [CrossRef]

57. Yao, Y.; Chen, J.; Lu, J.J.; Zhang, R.Q.; Zhao, L.H. Composition, trace element and infrared spectrum of garnet from three types of W-Sn bearing skarns in the South of China. Acta Mineral. Sin. 2013, 33, 315-328. (In Chinese)

58. Gaspar, M.; Knaack, C.; Meinert, L.D.; Moretti, R. REE in skarn systems: A LA-ICP-MS study of garnets from the Crown Jewel gold deposit. Geochim. Cosmochim. Acta 2008, 72, 185-205. [CrossRef]

59. Mcintire, W.L. Trace element partition coefficients-a review of theory and applications to geology. Geochim. Cosmochim. Acta 1963, 27, 1209-1264. [CrossRef]

60. Meinert, L.D.; Dipple, G.M.; Nicolescu, S. World skarn deposits. Soc. Econ. Geol. 2005, 100th Anniversary Volume, 299-336.

61. Eugster, H.P. Granites and hydrothermal ore deposits: A geochemical framework. Mineral. Mag. 1985, 49, 7-23. [CrossRef]

62. Zhang, Y.; Liu, Q.Q.; Shao, Y.J.; Li, H.B. Fingerprinting the hydrothermal fluid characteristics from LA-ICP-MS trace element geochemistry of garnet in the Yongping Cu deposit, SE China. Minerals 2017, 7, 199. [CrossRef]

63. Menzer, G. Die Kristallstruktur der granate. Z. Krist.-Cryst. Mater. 1929, 69, 300-396. [CrossRef]

64. Xu, J.; Ciobanu, C.L.; Cook, N.J.; Zheng, Y.Y.; Sun, X.; Wade, B.P. Skarn formation and trace elements in garnet and associated minerals from Zhibula copper deposit, Gangdese Belt, southern Tibet. Lithos 2016, 262, 213-231. [CrossRef] 
65. Zhao, P.L.; Yuan, S.D.; Yuan, Y.B. Geochemical characteristics of garnet in the Huangshaping polymetallic deposit, Southern Hunan: Implications for the genesis of $\mathrm{Cu}$ and W-Sn mineralization. Acta Petrol. Sin. 2018, 34, 2581-2597. (In Chinese)

66. Nekrasov, I.Y. Features of tin mineralization in carbonate deposits, as in Eastern Siberia. Int. Geol. Rev. 1971, 13, 1532-1542. [CrossRef]

67. Mclver, J.R.; Mihalik, P. Stannian andradite from “Davib Ost”, South West Africa. Can. Mineral. 1975, 13, 217-221.

68. Amthauer, G.; Mciver, J.R.; Viljoen, E.A. ${ }^{57} \mathrm{Fe}$ and ${ }^{119} \mathrm{Sn}$ Mossbauer studies of natural tin-bearing garnets. Phys. Chem. Miner. 1979, 4, 235-244. [CrossRef]

69. Plimer, I.R. Malayaite and tin-bearing silicates from a skarn at Doradilla via Bourke, New South Wales. Aust. J. Earth Sci. 1984, 31, 147-153. [CrossRef]

70. Kwak, T.A.P. W-Sn skarn deposits and related metamorphic skarns and granitoids. Dev. Econ. Geol. 1987, 24, $1-451$.

71. Guo, S.; Chen, Y.; Liu, C.Z.; Wang, J.G.; Su, B.; Gao, Y.J.; Wu, F.Y.; Sein, K.; Yang, Y.H.; Mao, Q. Scheelite and coexisting F-rich zoned garnet, vesuvianite, fluorite, and apatite in calc-silicate rocks from the Mogok metamorphic belt, Myanmar: Implications for metasomatism in marble and the role of halogens in $\mathrm{W}$ mobilization and mineralization. J. Asian Earth Sci. 2016, 117, 82-106. [CrossRef]

72. Kwak, T.A.P.; White, A.J.R. Contrasting W-Mo-Cu and W-Sn-F skarn types and related granitoids. Min. Geol. 1982, 32, 339-351.

73. Liao, S.L.; Chen, S.Y.; Deng, X.H.; Li, P.; Zhao, J.N.; Liao, R.Y. Fluid inclusion characteristics and geological significance of the Xi'ao copper-tin polymetallic deposit in Gejiu, Yunnan Province. J. Asian Earth Sci. 2014, 79, 455-467. [CrossRef]

74. Mei, W.; Lü, X.B.; Cao, X.F.; Liu, Z.; Zhao, Y.; Ai, Z.L.; Tang, R.K.; Abfaua, M.M. Ore genesis and hydrothermal evolution of the Huanggang skarn iron-tin polymetallic deposit, southern Great Xing'an Range: Evidence from fluid inclusions and isotope analyses. Ore Geol. Rev. 2015, 64, 239-252. [CrossRef]

75. Lu, H.Z.; Liu, Y.M.; Wang, C.L.; Xu, Y.Z.; Li, H.Q. Mineralization and fluid inclusion study of the Shizhuyuan W-Sn-Bi-Mo-F skarn deposit, Hunan Province, China. Econ. Geol. 2003, 98, 955-974. [CrossRef]

76. Liu, X.F. Geology, Geochemistry and Genesis of the Jinchuantang Tin-Bismuth Deposit, Hunan Province. Master's Thesis, China University of Geosciences (Beijing), Beijing, China, 2014.

77. Saksela, M. Zur Mineralogie und Entstehung der Pitkäranta-Erze. Bull. Comm. Géol. Finl. 1951, 154, $182-230$.

78. Park, C.; Song, Y.; Kang, I.M.; Shim, J.; Chung, D.; Park, C.S. Metasomatic changes during periodic fluid flux recorded in grandite garnet from the Weondong W-skarn deposit, South Korea. Chem. Geol. 2017, 451, 135-153. [CrossRef]

(C) 2020 by the authors. Licensee MDPI, Basel, Switzerland. This article is an open access article distributed under the terms and conditions of the Creative Commons Attribution (CC BY) license (http://creativecommons.org/licenses/by/4.0/). 